\title{
Assessing and Forecasting of Groundwater Level Fluctuation in Joypurhat District, Northwest Bangladesh Using Wavelet Analysis and ARIMA Modeling
}

\author{
Almamunur Rashid \\ Jashore University of Science and Technology \\ Mahiuddin Alamgir \\ Jiujiang University \\ Mohamad Tofayal Ahmed \\ Jashore University of Science and Technology \\ Roquia Salam \\ Begum Rokeya University \\ Abu Reza Md. Towfiqul Islam ( $\nabla$ towfiq_dm@brur.ac.bd) \\ Begum Rokeya University https://orcid.org/0000-0001-5779-1382 \\ Aminul Islam \\ Jashore University of Science and Technology
}

\section{Research Article}

Keywords: ARIMA modeling, Pettit test, GWL declination, groundwater resource, northwest Bangladesh

Posted Date: November 11th, 2021

DOI: https://doi.org/10.21203/rs.3.rs-1001988/v1

License: (a) (i) This work is licensed under a Creative Commons Attribution 4.0 International License.

Read Full License 
Assessing and forecasting of groundwater level fluctuation in Joypurhat 2 district, northwest Bangladesh using wavelet analysis and ARIMA modeling

3

\section{Almamunur Rashid ${ }^{a}$, Mahiuddin Alamgir ${ }^{\mathrm{b}}$, Mohamad Tofayal Ahmed ${ }^{\mathrm{a}}$, Roquia Salam} Abu Reza Md. Towfiqul Islam ${ }^{\mathrm{c} *}$,Aminul Islam*

${ }^{a}$ Department of Petroleum and Mining Engineering, Jashore University of Science and Technology, Jashore 7408, Bangladesh

${ }^{b}$ School of Civil Engineering, Jiujiang University, Jiujiang 332005, China

${ }^{c}$ Department of Disaster Management, Begum Rokeya University, Rangpur 5400, Bangladesh

*Corresponding Author

aminul_pme@just.edu.bd (A. Islam); towfiq_dm@brur.ac.bd (Abu Reza Md. Towfiqul Islam)

(1)

3

\section{4}

5

6

7

8

9

30

1

2


Abstract:

34 Groundwater resource plays a crucial role for agricultural crop production and socio-economic 35 development in some parts of the world including Bangladesh. Joypurhat district, the northwest 36 part of Bangladesh, a crop production hub, is entirely dependent on groundwater irrigation. A

37 precise assessment and prediction of groundwater level (GWL) can assist long-term GWR 38 management, especially in drought-prone agricultural regions. Therefore, this study was carried 39 out to identify trends and magnitude of GWL fluctuation (1980-2019) using the Modified Mann40 Kendall test, Pettitt's Test, and Sen Slope estimators in the drought-prone Joypurhat district, 41 northwest Bangladesh. Time-series data analysis was performed to forecast GWL from 2020 to 422050 using the Auto-Regressive Integrated Moving Average (ARIMA) model. The findings of 43 the MMK test revealed a significant declining trend of GWL, and the trend turning points were 44 identified in the years 1991, 1993, 1997, and 2004, respectively. Results also indicate that the 45 declining rate of GWL varied from $0.104 \mathrm{~m} / \mathrm{yr}$ to $0.159 \mathrm{~m} / \mathrm{yr}$ and the average rate of GWL 46 declination was $0.136 \mathrm{~m} / \mathrm{yr}$ during 1980-2019. The outcomes of wavelet spectrum analysis 47 depicted two significant periods of the declining trend in Khetlal and Akkelpur Upazilas. The 48 results obtained from the optimal identified model ARIMA $(2,1,0)$, indicating that GWL will 49 decline at a depth of $13.76 \mathrm{~m}$ in 2050 , and the average declination rate of GWL will be 0.143 $50 \mathrm{~m} / \mathrm{yr}$ in the study area. The predicted results showed a similar declining tendency of GWL from 512020 to 2050, suggesting a disquieting condition, particularly for Khetlal Upazila. This research 52 would provide a practical approach for GWL assessment and prediction that could help decision53 makers implement long-term GWR management in the study area.

54 Keywords: ARIMA modeling, Pettit test, GWL declination, groundwater resource and 55 northwest Bangladesh 


\section{Introduction}

57 Groundwater is one of the top valuable natural resources in the world. It plays a pivotal role in

58 the economic, social, and environmental sustainability context. The potential use of groundwater,

59 particularly in agricultural-based developing countries like Bangladesh, is a paramount concern

60 to the policy-makers on groundwater resources (GWR) management perspective (Morris et al.

61 2003; Mackay et al. 2015; Salam et al., 2020a; Islam et al. 2021a). In recent times, climate

62 variability (e.g., rainfall infiltration rate, surface runoff, evaporation, and increase in

63 temperature), rapid population increase, and over-exploitation have a detrimental effect on this

64 valuable GWR in many drought-prone regions worldwide (Shahid and Hazarika, 2010; Cheng et

65 al., 2016; Kalhor and Emaminejad, 2019; Yadav et al., 2020; Ajibade et al. 2021). This is

66 primarily genuine for northwest region of Bangladesh, where high population density and

67 increasing agricultural crop production raise water demand (Shahid 2011; Husna et al. 2016;

68 Islam et al., 2020). As a result, GW levels (GWL) are declining and rising water scarcity in the

69 drought-prone Barind tract region. However, groundwater scarcity is another challenge around

70 the globe. GWL assessment and prediction is an integrated part of the investigation for

71 sustainable GWR management. In addition to management concerns, the long-term prediction

72 will be helpful to close missing dataset too. Thus, accurate GWL assessment and prediction are

73 crucial for effective and sustainable GWR management in water-stressed regions, especially in

74 Bangladesh's northwest drought-prone region.

75 The use of groundwater in the irrigation sector for crop production is increasing significantly in

76 Bangladesh. In such a case, the northwest region of Bangladeshis is facing the critical condition

77 of groundwater due to the impact of over-exploitation. Abstraction of groundwater from deep

78 tube wells has resulted in substantial increases in agricultural production and significant falls in 
aquifers' groundwater heads (Patle et al. 2015; Rushton et al. 2020; Mallick et al. 2021). More than $75 \%$ of irrigation water is managed by the groundwater withdrawal in the northwest part of Bangladesh (Shahid and Hazarika 2010). During the dry season, most surface water resources like rivers, canals, beels (static water bodies), ponds, and other reservoirs get dried because of limited rainfall and other adverse climatic factors that compel people to use groundwater in the northwest part of Bangladesh. When groundwater withdrawal exceeds the natural recharge to groundwater storage for a long time in a considerable area, the declination of GWL occurs. The falling trends of groundwater levels indicate that groundwater exploitation exceeds the recharge, indicating unsustainable withdrawal (Zannat et al. 2019). The GWL declining rate is higher in the northern region than in the southern part (Sumiya and Khatun 2016). The groundwater table has reduced noticeably in northwest part of Bangladesh due to the over-exploitation of groundwater (Dey et al. 2017).

Joypurhat district is an agricultural hub of the country. In this area, farmers use many irrigation equipment to withdraw groundwater for irrigation purposes to boost up cropping intensity (Islam et al. 2018). Rice and potato are the main crops in this area which are both high water-consuming crops, and their cultivation relies on groundwater irrigation. The groundwater table in most of the Kalai, Khetlal, Panchbibi, and Akkelpur Upazilas goes below suction limit causing hand tubewells and shallow tube-wells partially/fully operable (Hossain et al. 2015). Intensive agricultural, rapid industrial development, and domestic demand have put more pressure on groundwater use and accelerated the rate of water table declination in this area. These conditions demand the proper monitoring and investigations in GWL depletion. The trend analysis will help in understanding the variation, changing direction, and trend of GWL and GWL projection for future management. 
102 Few researchers in Bangladesh have studied GWL depletion at the natural and regional levels 103 (Jahan et al. 2010; Rahman et al. 2016; Dey et al. 2017; Salam et al. 2020a). Many research 104 scholars have been investigated the reasons and magnitudes of GWL depletion in NW 105 Bangladesh. For example, Zafor et al. (2017) concentrated on the falling trend direction in GWL, 106 which implies an unbalanced groundwater setting in northern Bangladesh. Zahid (2015) reported 107 that the tendency of GWL fluctuation is elevated in Bangladesh's northwest Barind area. Rahman 108 109 110 in wetland area, and scarcity of water reservoir. Although the rapid rise in the irrigated cropping 112 area during the last two decades, poorer performance and lack of groundwater efficacy and 113 surface water utilization are yet hindrances for substantial GWR management. Groundwater is 114 mostly used in the irrigated cultivation areas; however, its sustainability is at higher risk 115 according to quality and quantity of groundwater in northwest Bangladesh (Shahid 2011). Yet, 116 irregular trend pattern and changing characteristics of GWL are unexplored in the vital drought117 prone region. Therefore, it is essential to better insight into the unusual trend behavior, changing 118 pattern in GWL, and future situations of groundwater fluctuation in northwest Bangladesh.

119 No such comprehensive study has been performed before in the drought-prone region, part of 120 Barind Tract, Joypurhat district of northwest Bangladesh. This type of study is urgently required 121 due to severe water-stressed condition. In this study, the modified Mann-Kendall test, Sen Slope 122 estimator, Pettitt's test, and Wavelet power spectrum analyses have been applied first time to 123 find out the spatial and temporal trend patterns of GWL variation in the Joypurhat district, 124 northwest Bangladesh. On the other hand, statistical analyses require a more in-depth 
125 understanding of future GWL characteristics. Due to the oversimplification of complicated

126 hydrological mechanisms and the scarcity of groundwater datasets, achieving precise forecasting

127 through statistical methods, such as the Auto-Regressive Integrated Moving Average (ARIMA),

128 is a promising task (Rahman et al. 2017 Akhter et al. 2019; Salam et al. 2020a). Another aim of

129 this study is to forecast the GWL from 2020 to 2050 in the study area using the ARIMA

130 modeling. The novelty of this work is that an integrated statistical approach is applied to assess

131 and predict GWL for sustainable GWR management at the regional level. The findings of this

132 study can aid in accepting the proper decision to policymakers in the further installation of

133 irrigation equipment and sustainable use of groundwater resources in this area or similar region

134 around the world.

135 2. Data and Methods

$136 \quad 2.1$ Study area description

137 Joypurhat district has been selected for the study area located in the Barind tract in the North138 West region of Bangladesh. It is situated between $24^{\circ} 46^{\prime} \mathrm{N}$ to $25^{\circ} 22^{\prime} \mathrm{N}$ latitude and $88^{\circ} 56^{\prime} \mathrm{E}$ to $13989^{\circ} 14^{\prime}$ E longitude shown in Fig. 1. Joypurhat district is bounded on the north by Gaibandha 140 district, Dinajpur district and India border, on the south by Bogra district and Naogaon district, 141 on the east by Bogra district and Gaibandha district, and on the west by Naogaon district and 142 India border. The total area of the district is $965.88 \mathrm{~km}^{2}$ (Islam et al. 2018) It consists of five 143 Upazilas, namely Joypurhatsadar, Akkelpur, Khetlal, Kalai, and Panchbibi. The economy of 144 Joypurhat district is entirely dependent on agriculture and is famous for its granaries. There are 1451978 nos shallow, deep tube-wells (DTW) and 8050 nos. Shallow tube-wells (STW) are used for 146 irrigation purposes in agricultural production (BADC 2019). The study region shows a rich 147 agricultural hub of about 80270 ha net cultivatable site, which depends on groundwater 
148 irrigation. Rice and potatoes are the main cash crops of this area. Both crops are highly water149 consuming in an irrigated field. Water scarcity is a common problem during the dry winter 150 period in the study area.

\section{$151 \quad 2.2$ Geology and hydrological conditions}

152 The Joypurhat district is the portion of the Tista floodplain that belonged to the shelf region 153 (Bogra slope), encompassing Himalayan Foredeep region of Bengal Basin (Reimann and Hiller 154 1993). The study area lies in the sub-humid area bounded by geological formations deposited 155 from the DupiTila Sandstone Formation. The sediment is deposited as an older alluvial fan 156 where different rivers flowing through the study areas like: Chiri River and Haraboti River cross 157 via Panchbibi Upazila. Small Jamuna River crosses via Joypurhat Sadar and Panchbibi Upazilas. 158 Tulshiganga River passes via Joypurhat Sadar, Khetlal, and Akkelpur Upazilas. Sree River 159 crosses via Joypurhat Sadar Upazila.

160 The topography of the study area varies from $24 \mathrm{~m}$ in Panchbibi to $14.4 \mathrm{~m}$ in Akkelpur. The 161 study area is relatively flat, sloping from North to South direction. The topsoil of the study area 162 is mainly clay and the aquifer properties like Transmissivity varies from $1240 \mathrm{~m}^{2} /$ day to 1700 $163 \mathrm{~m}^{2}$ /day (IWM 2009). The principal aquifers of the study area consist of fine sands, medium 164 sands, and coarse sands with mild stone particles, as shown in Fig. 2 (a-e).

165 Considering the lithological characteristics of five selected wells in the study area, the average 166 thickness of the aquifers in the Joypurhat district varies from about 40m to $51 \mathrm{~m}$. The screenable 167 thickness of the study area is ranged from $29.39 \mathrm{~m}$ to $35.06 \mathrm{~m}$, with a bore depth up to $65 \mathrm{~m}$ from 168 the ground surface. Joypurhat is a district of sub-tropical climate. The average annual 169 temperature is $24.4{ }^{\circ} \mathrm{C}$, and the average annual rainfall is $1673 \mathrm{~mm}$. More than $60 \%$ of rains 170 occur in July-August, with an average of $364 \mathrm{~mm}$ (Das and Islam, 2021). The pre-monsoon 
171 period occurs from March to May, and the monsoon period occurs from June to October. The

172 warmest month of the year is May, with the mean temperature of $28.9^{\circ} \mathrm{C}$ (Das 2021). The coldest

173 month of the year is January, with the average temperature are $18^{\circ} \mathrm{C}$, and the average annual

174 evaporation of the study area is around $1060 \mathrm{~mm}$ (Salam et al. 2020b).

175

176

177

178

179

180

181

182

183

184

185

186

187

188

189

190

191

192

193

\subsection{Data source and quality control check}

The monthly GWL data (1980-2019) of the different stations under Joypurhat district were collected from Bangladesh Water Development Board (BWDB), Dhaka. Since there is no station of BWDB at Akkelpur and Kalaiupazila for measuring GWL data (1980-2019), the Nearest station such as Parbotipur and Nischinta of the study area are used respectively for Akkelpur and Kalai Upazila. The monthly rainfall, evaporation, and temperature data from Bangladesh Meteorological Department (BMD) are used for the study area. In all cases, systematic quality control techniques are applied to evaluate data quality. All the data used in the study area are significant at $99 \%$ confidence level (p-value <0.001) in the Buishand Range test, Normality, and Homogeneity test. These tests also revealed that the data remain of good quality.

\subsection{Modified Mann-Kendall test}

Modified Mann-Kendall test is the modified version of the non-parametric Mann-Kendall test, which is robust tool in the presence of autocorrelation. This test may be used to identify trend detection in hydro-meteorological data series when datasets are non-random and impacted by autocorrelation (Mann, 1955; Kendall 1975). Hamed and Rao (1998) have first developed a variance correction method to address serial correlation in trend assessment. Praveen et al. (2020) have also suggested the same approach in this respect. Datasets are primarily detrended, and the adequate sample size is computed using the ranks of significant serial correlation analysis which are then used to correct the test statistic's inflated (or deflated) variance. 
194 The Mann-Kendall test statistics $\mathrm{S}$ is given as

$195 S=\sum_{i=1}^{n-1} \sum_{j=i+1}^{n} \operatorname{sgn}(X j-X i)$

196 Where, S is Mann-Kendall statistic and sgn is the signum function. Each of the data point xi is

197 taken as a reference point which is compared with the rest of the data points $\mathrm{xj}$ as follows:

$198 \quad \operatorname{sgn}(\mathrm{Xj}-\mathrm{Xi})=\left\{\begin{array}{c}1 \text { if }(X j-X i)>0 \\ 0 i f(X j-X i)=0 \\ -1 \text { if }(X j-X i)<0\end{array}\right.$

199 The value $\mathrm{S}$ shows the direction of trend. A positive value of $\mathrm{S}$ indicates an upward trend and 200 negative value indicates downward trend (Islam et al., 2021b; Jerin et al. 2021). The test 201 statistics $\mathrm{S}$ is expressed as

$202 \quad \mathrm{~V}(\mathrm{~S})=\frac{n(n-1)(2 n+5)-\sum_{i=1}^{m} t i(i)(i-1)(2 i+5)}{18}$

203

204 Where, $t_{i}$ is the number of ties up to sample $\mathrm{i}$. The modified variance $\mathrm{V}^{*}(\mathrm{~S})$ is given by the 205 following equation proposed by Yue and Wang (2004).

$206 \quad \mathrm{~V}^{*}(\mathrm{~S})=\mathrm{V}(\mathrm{S}) \cdot \frac{n}{n^{*}}$

207 Where $\frac{n}{n *}$ is considered as correction factor and it is calculated by the following equation 208 derived by Bayley and Hammersley (1946).

$209 \quad \frac{n}{n *}=1+2 \cdot \sum_{k=1}^{n-1}\left(1-\frac{k}{n}\right) \cdot \rho k$

210 In time series analysis, the presence of a statistically significant trend is calculated using Zc

211 value.

$212 \quad \mathrm{Zc}=\left\{\begin{array}{c}\frac{s-1}{\sqrt{V *(S)}} \text { if } S>0 \\ 0 \text { if } s=0 \\ \frac{s+1}{\sqrt{V *(S)}} \text { if } S<0\end{array}\right.$ 
213 In this method, a positive value of indicates an increasing trend a negative value indicates

214 decreasing trend. The trend is considered as statistically significant in this study when $\mathrm{p} \leq 0.05$ at

$2155 \%$ significance level.

$216 \quad 2.5$ Sen's Slope Estimator

217 Sen's slope estimator test is a non-parametric method (Sen,1968) which is used to estimate the 218 magnitude of trends (change per unit time) in time series data. The magnitude of trend is 219 expressed as Q calculated by the Eq. (7):

$220 \mathrm{Q}=\frac{\mathrm{Xj}-\mathrm{Xk}}{j-k}$

221 Where, $X_{j}$ and $X_{k}$ are denoted by data values at times $j$ and $k(j>k)$ respectively. A positive value

222 of Q indicates an increasing trend and negative value indicates decreasing trend in time series

223 data.

\section{$224 \quad 2.6$ Pettitt's test}

225 The pettitt's test is a common non-parametric technique which was used to detect an abrupt 226 change point in hydrological time series datasets (Pettitt 1979). The non-parametric statistics is 227 defined as follows:

$228 \mathrm{~K}_{\mathrm{T}}=\mathrm{MAX}\left|\mathrm{U}_{\mathrm{t}, \mathrm{T}}\right|$

229 Where, $\mathrm{U}_{\mathrm{t}, \mathrm{T}}=\sum_{i=1}^{t} \sum_{j=t+1}^{T} \operatorname{sgn}(X i-X j)$

$230 \mathrm{~K}_{\mathrm{T}}$ is the location point where the abrupt change point of time series data occurred. The 231 probability of significance level of $\mathrm{K}_{\mathrm{T}}$ is approximately lied on $\mathrm{p} \leq 0.05$ followed by equation 232 (10).

$233 \mathrm{p} \cong 2 \exp \left(\frac{-6 K T 2}{T 3+T 2}\right)$

\section{$234 \quad 2.7$ Wavelet transform analysis}


235 Wavelet analysis is a common tool to analyze local spectral and temporal variations of power

236 within a time series for a particular scale and location. It contains non-stationary power at

237 various frequencies (Jerin et al. 2021; Rahman et al., 2021). Depending on time and non-

238 dimensional frequency Morlet wavelet consists of a plane wave modulated by Gaussian

239 following by the equation (11).

$240 \quad \Psi_{0}(\eta)=\pi^{-1 / 4} e^{i \omega 0 \eta} e^{-\eta 2 / 2}$

241 Where $\Psi_{0}(\eta)$ is denoted by wavelet value at non-dimentional time $\eta$ and $\omega 0$ is the non-

242 dimensional frequency, here taken to be (equation 6) in this study in order to satisfy the

243 admissibility condition (Farge 1992). According to the function of basic wavelet, the scaled

244 wavelets are ascertained as follows:

$245 \Psi\left[\frac{\left(n^{\prime}-n\right) \delta t}{S}\right]=\left(\frac{\delta t}{S}\right)^{1 / 2} \cdot \Psi_{0}\left[\frac{\left(n^{\prime}-1\right) \delta t}{S}\right]$

246 Where $\mathrm{S}$ is dilation parameter used to change the scale and $\mathrm{n}$ is the translation parameter used to

247 slide in time. The wavelet transform $\mathrm{W}_{\mathrm{n}}(\mathrm{S})$ is expressed as the convolution of the wavelet

248 function which is defined by the following equation (13):

$249 \quad \mathrm{~W}_{\mathrm{n}}(\mathrm{S})=\sum_{n^{\prime}}^{\mathrm{N}-1} x n^{\prime} \Psi *\left[\frac{\left(n-n^{\prime}\right) \delta t}{S}\right]$

250 Where $\Psi^{*}$ indicates the complex conjugate and $\mathrm{n}$ is the localized time index.

251

\section{$252 \quad 2.8$ ARIMA modeling}

253 Auto-Regressive Integrated Moving Average (ARIMA) model is the popular technique for 254 modeling time series data and predicting future data in a series (Box and Jenkins 1976; Rahman 255 et al., 2017; Akhter et al., 2019; Islam et al., 2020). In this study, a non-seasonal ARIMA model 256 is subjected to understand past data for forecasting. It consists of three statistics parts such as 257 autoregressive (AR) terms, Integrated (I) term, and moving average (MA) term. These terms are 
258 classified as $\operatorname{ARIMA}(\mathrm{p}, \mathrm{d}, \mathrm{q})$ in which $\mathrm{p}$ is an autoregressive part that forecasts future values

259 based on past value, $d$ is integrated part used for removing non-stationarity in forecasting, and $q$

260 is the moving average part used for maintaining lagged forecast errors in the prediction system.

261 In this study, the time series of GWL data (denoted by Y) was used to assign appropriate models

262 and forecasting. In terms of $\mathrm{Y}$, the general forecasting equation could be expressed as follows

263 with the convention introduced by Box and Jenkins (1976).

$264 \quad \hat{\mathrm{Y}}_{\mathrm{t}}=\boldsymbol{=} \mu \varphi_{1} \mathrm{Y}_{\mathrm{t}-1}+\ldots+\varphi \mathrm{Y}_{\mathrm{t}-\mathrm{p}}-\theta_{1} \mathrm{e}_{\mathrm{t}-1}-\ldots-\theta_{\mathrm{q}} \mathrm{e}_{\mathrm{t}-\mathrm{q}}$

265 Where $\hat{Y} t_{\text {is }}$ the forecasted value at time $t, \mathrm{Y}_{\mathrm{t}-1}$ is the previous forecasted value, $\mu$ is constant term, $266 \varphi$ is autoregressive parameter and $\theta$ is the moving average parameter.

267 The Box and Jenkins method of ARIMA modeling follows four steps to choose the best model 268 and forecasting. These steps are model identification, parameter estimation, diagnostic checking, 269 and forecasting. In the first step, the time series must be standardized and normalized by proper 270 order differencing. The most popular method for identifying the appropriate demands of an 271 ARIMA model is the adjustment behavior of autocorrelation function (ACF) and partial 272 autocorrelation function (PACF). In 2nd step, model parameters are estimated by the maximum 273 likelihood method. Model adequacy is performed with diagnostic checking if the errors of model 274 assumptions are satisfied. When the model seems inadequate, a new tentative model is assigned. 275 The steps described above are repeated until the model assumption associated with the error is 276 satisfied, and a satisfactory model is finalized. At last, the finally selected model is used for 277 ARIMA fitting and forecasting.

278 In the present study, SPSS software was used for ARIMA modeling. Time series data of GWL 279 were partitioned as the ratio 30:10. The first part of time series data from 1980-2009 was used 280 for model identification, and 2nd part of the time series from 2010-2019 was used for model 
281 validation and model performance and predictability testing. Bayesian Information Criteria

282 (BIC) is firstly considered for the efficiency evaluation of model performance. Lastly, the most

283 appropriate forecasting model was finally chosen based on model fit statistics value of $\mathrm{R}^{2}$,

284 RMSE, MAPE, MaxAPE, MaxAE, and Ljung-Box statistics.

285 3. Results

$286 \quad 3.1$ Variation in climatic parameters

287 Rainfall, temperature, and evaporation distributions play an essential role in GWL fluctuating in 288 a specific area. Fig. 3(a-c) showed the monthly maximum and minimum temperature and rainfall 289 distributions of the northwest region, Joypurhat district. The hottest month is identified as April 290 to May, and the coldest month is January. The highest rainfall occurred in July, and the lowest 291 rainfall occurred in January. It is observed that heavy rain happened in temperature $24^{\circ}-35^{\circ} \mathrm{C}$ in 292 July. It is also noticeable that GWL started depletion in the hottest month due to high 293 temperature and evaporation differences. Again, groundwater level started rising toward the 294 ground surface when temperature and evaporation decreased at a favorable condition to increase 295 rainfall.

\section{$296 \quad 3.2$ Apparent variation in groundwater level}

297 Consecutive records of GWL are essential for assessing groundwater fluctuation and its trend, as 298 well as groundwater potentiality. The observed GWL data generally represent the apparent 299 variation of groundwater table in a study area. To understand the noticeable variation of GWL, 300 the following Fig. 4(a-e) are produced. It is observed that the groundwater table is highly 301 depleted in April due to groundwater pumping for irrigation, high temperature, 302 evapotranspiration, and other related climatic factors. But GWL is raised towards the ground 303 surface in September for high monsoon rainfall which enhances the recharging groundwater 
storage. According to the Fig. 4(a-e) annual groundwater depth variation limit is maximum (7.07 $\mathrm{m})$ in Khetlal and minimum (4.6 m) in Panchbibi Upazila. It was also observed that the highest GWL declination from the ground surface is $12.82 \mathrm{~m}$ in Khetlal and the lowest GWL declination is $2.35 \mathrm{~m}$ in Akkelpur Upazila. It can be mentioned that amount of groundwater pumping, temperature, evapotranspiration, and rainfall distribution might affect the apparent variation of

309 GWL. During the dry season, adverse climate and rate of groundwater pumping for irrigation reach the extreme level, and rainfall is limited; thus, GWL declination is increased.

311 On the other hand, favorable climatic conditions, limited groundwater irrigation, and heavy 312 rainfall create an auspicious situation during the wet season, so GWL declination started 313 decreasing, and GWL rose towards the ground surface successively. Therefore, GWL is highly 314 depleted in April and increasing towards the ground surface in September-October. The highest 315 decreasing rate of GWL was found in Khetlal Upazila. The lowest decreasing rate was found in 316 Panchbibi Upazila of Joypurhat district, situated in the northwest region of Bangladesh.

\section{$317 \quad 3.3$ Trend of groundwater level fluctuation}

318 The modified Mann-Kendal test is carried out in time-series data (1980-2019) on a monthly 319 scale. The Modified Mann-Kendal test is carried out in time-series data (1980-2019) on the monthly GWL in selected stations of different Upazilas of Joypurhat district. To find out the

321 trend in time series GWL, MMK 'Zc' statistics were determined shown in Table 2. In all cases, 322 'Zc' values are at a 5\% level of significance. So, it can be said that the null hypothesis was 323 rejected, and there was found a significant trend in time series data of groundwater levels. The 324 positive sign 'Zc' statistics were suggested that GWL was declining for the ground surface.

325 The 'Zc' statistics values obtained from the MMK test are varied from 7.37 to 17.78 in different 326 stations, respectively. It is observed that the lowest declining trend $(\mathrm{Zc}=17.78)$ of GWL level is 
327 found at Panchbibi Upazila. The comparatively highest declining trend $(\mathrm{Zc}=7.37)$ is found at

328 Khetlal Upazila of the study area, which is shown in Fig. 5.a. After determining the trend, Sen's

329 slope estimator was applied to calculate the slope of trend/ rate of groundwater level declination

330 (Q) in m/decade (Table 1) during the period 1980-2019. The Sen's slope value (Q) obtained from

331 the MMK test varies from 0.10405 to $0.15964 \mathrm{~m} / \mathrm{yr}$. Fig. 5.b shows that the high rate of GWL

332 level declination(Sen's slope, Q ) is found at ketal and Kalai Upazilas, medium changing rate at

333 Joypurhat Sadar and Akkelpur, low at Panchbibi Upazila, which is illustrated in Fig. 5.c.After

334 determining trend status and trend slope, the change point of GWL was identified at the time of

335 Dec '91, Dec '93, Jan '97, Feb '97, and Dec '04 for Akkelpur, Joypurhatsadar, Khetlal, Kalai, and

336 Panchbibi Upazila, respectively following the result of Pettitt's test which is shown in Fig. 6.

337 GWL level declination trend was started the first atAkkelpur in 1991 and then Joypurhat sadar in

338 1993, Khetlal and Kalai in 1997, and Panchbibi in 2004, respectively. It can be said that the

339 groundwater pumping in Khetlal and Kalaiupazila during the dry season is more than in the other

340 Upazilas. Two Upazilas are more vulnerable to groundwater resources than others.

3.4 Wavelet transformation of groundwater level

342 Morlet wavelet power spectrum of GWL level is shown in Fig. 7(a-f). The black contour line

343 identifies the significance level, and the black line marks the cone of influence. An analysis of

344 the wavelet power spectrum, it is observed that two significant periods of increasing trend were

345 detected in Khetlal Upazila in a scale range 4.0-6.0 from 1980-1992, scale range 11.4-16 from

346 1992-2019, and Akkelpur Upazila in a scale range 6.9-11.2 from 1980-1993, range 11.4-16 from

347 1994-2019. Only one significant period of increased GWL level is detected in Joypurhat Sadar,

348 Panchbibi, and Kalai Upazila. However, one significant period of GWL level increasing trend

349 started from 1991-2019 in Joypurhat district. 


\subsection{ARIMA model selection and validation}

351 Plots of the autocorrelation function (ACF)and partial autocorrelation (PACF) are crucial for ARIMA model selection. Based on plots of ACF and PACF, the order $\mathrm{p}$ and $\mathrm{q}$ were decided to

develop the tentative ARIMA models for the 1980-2019 time series of groundwater levels. For each station, tentative ARIMA models were selected for every 10 (Ten) years with different orders of p,d,q with reasonable ranges. The tested models were as follows:(0,0,0), $(0,1,0),(0,1,1),(1,1,0),(1,1,1),(1,1,2),(2,1,1),(2,1,2),(0,1,2),(2,1,0)$.To analyze the ACF and PACF residuals plots within the confidence limit, some tentative suitable models for each station were selected based on normalized BIC. Out of these selected models, the best appropriate models for time series groundwater levels of each station were chosen based on the lowest $\mathrm{R}$ squared, RMSE, MAPE, MaxApE, MAE, MaxAE, and Ljung-Box Q statistics shown in Table 3.

Similarly, the best model for the Joypurhat district was identified as the ARIMA model $(2,1,0)$ by evaluation of ACF and PACF plots and model goodness of fit statistics. This model's ACF and PACF plots for the Joypurhat district are shown in Fig.8(a-c). Comparison of observed GWL during 2010-2019 was accomplished for further validation of selected ARIMA model for each station and Joypurhat district. Comparison plot of observed GWL vs. forecasted GWL during 2010-2019 of Joypurhat district average are in good consistency with obtained R squared value of 0.7544 for Joypurhat district Fig. 9. So, the selected ARIMA model for the study area was considered for forecasting GWL.

\subsection{Forecasting of groundwater levels}

The selected best models for each station and Joypurhat district were applied to forecast GWL shown in Fig. 10 (a-f). It is found that GWL would decline linearly from 2020 onwards in Joypurhat Sadar, Panchbibi, Akkelpur, Kalai, and Khetlal Upazilas. These forecasting results 
373 reveal a sharp trend of increasing from the ground surface in Khetlal, Kalai, and Akkelpur

374 upazila. A moderate trend in GWL decreasing from the ground surface is located in Joypurhat

375 Sadar and Panchbibi upazila.

376 Overall, a moderate increasing trend of GWL levels from the ground surface was found in the 377 Joypurhat district. As seen from Fig. 10(a-c), the predicted GWL levels would reach 12.18m, $37810.72 \mathrm{~m}, 11.17 \mathrm{~m}, 16.27 \mathrm{~m}$, and $18.44 \mathrm{~m}$ in 2050 concerning the observed value of $3797.89 \mathrm{~m}, 7.54 \mathrm{~m}, 7.48 \mathrm{~m}, 11.69 \mathrm{~m}$, and $12.82 \mathrm{~m}$ in 2019 in Joypurhat sadar, Panchbibi, Akkelpur, 380 Kalai and Khetlal Upazilas, respectively. Overall, the GWL level of Joypurhat district would 381 reach $13.76 \mathrm{~m}$ in 2050 over the observed value of $9.48 \mathrm{~m}$ in 2019 . In Joypurhat district, the 382 observed average rate of declination in GWL level was found $0.136 \mathrm{~m} / \mathrm{yr}$ from 1980 to 2019 as 383 per Sen's estimator. The forecasted rate of declination during 2020-2050 was determined0.143 $384 \mathrm{~m} / \mathrm{yr}$, which shows a moderate increasing trend. The climate change effect, groundwater 385 irrigation, and rainfall distribution were evaluated to examine the predicted results. There was a 386 slight adverse effect on rainfall distribution and climate. But major factor affecting on 387 groundwater level declination trend might be the burning question for increased groundwater 388 irrigation in the agriculture development of the study area. In this area, rice and potato 389 production are the main crops entirely dependent on groundwater irrigation.

390 4. Discussion

391 This study explores the GWL fluctuation in a drought-prone Barint tract, namely the Joypurhat 392 district of northwest Bangladesh. GWL in Joypurhat district of northwest Bangladesh is 393 declining gradually. It is observed that the declining trend of GWL is more significant in Khetlal 394 and Kalaiupazilas than the other Upazilas. The main reason is that the flow of the Atria River 395 occurs in the upper part of the Joypurhat districts. The base flow happens in the SW direction 
because of the average slope, triggering the minimum aquifer recharge from river water in this

397 region. Besides, soil texture in this region is dominated by silty clay soil, which belongs to

398 relatively lower hydraulic conductivity characteristics (Zannat et al. 2019). Consequently,

399 groundwater recharge from rainfall is very low.

400 The rates of GWL change ranged from 1.04 to $1.59 \mathrm{~m} /$ decade during $1980-2019$ in Joypurhat

401 district. Salam et al. (2020a) found that the rates of GWL change vary from 0.1 to $1.3 \mathrm{~m} / \mathrm{decade}$

402 during 1981-2017in the Northwest part of Bangladesh. The outcome is in line with Zahid (2015)

403 and Rahman et al. (2016). The highest change point was detected at Khetlal Upazila in 1997.

404 After the 2000s, the GWL declines rapidly due to climatic effects (Islam et al. 2021b). This may

405 be happened due to huge boro rice and potato cultivation dependent on groundwater irrigation.

406 Wavelet analysis exhibits two significant periods of GWL in Khetlal and Akkelpur, whereas

407 Pahnchbibi shows no considerable period of GWL. Khetlal Upazila reveals a drier condition than

408 the wet condition of groundwater. The results of the ARIMA model reveals a rising trend of

409 declining GWL in Khetlal, and the trend of declining GWL is lower in Panchbibi than Kalai. The

410 rate of GWL declined from 2020 to 2050 will be $0.143 \mathrm{~m} /$ decade compared to the present period

411 (0.136 m/decade). These findings coincided with the outcome of Dey et al. (2017) and Gibrila et

412 al. (2018), where they observed significant variations in GWL across the North-West region of

413 Bangladesh. Salam et al. (2020a) found similar results in which GWL is going downwards in

414 pre-monsoon time and is rising upwards in post-monsoon in the northwestern region of

415 Bangladesh.

416 In recent times, the drought-prone humid region of northwest Bangladesh has experienced severe

417 scarcity of GWL due to the over-extraction of GW. Overexploitation of aquifer to offset the 418 balance between demand and supply and the variations in surface water flow rate are considered 
419 the major cause of GWL declination. The interaction of surface-groundwater is a complicated 420 system that relies on several factors, including the altitude of the groundwater table compared to

421 the altitude of the stream water, aquifer types, soil texture, and so on.

422 The long-term GWL fluctuation is a function of many-fold parameters, including annual rainfall, 423 annual groundwater withdrawal, and local subsurface geological conditions. The increase or 424 decrease of the precipitation can significantly affect GWL as it is the primary source for 425 groundwater recharge (Park et al., 2011). Consistent with a widespread and prevailing decreasing 426 trend in GWL over the study area, the decreasing trend of precipitation cannot be ignored as a 427 responsible factor. Local geology characterizes shallow aquifers in Bangladesh and essentially 428 controls the timing and pathways of groundwater recharge to aquifers (WARPO 2000). The 429 declining shallow groundwater storage in northwestern Bangladesh relates to the intensity of 430 abstraction of GW and areas of the high thickness of surface clay where rainfall-fed recharge 431 rates are low due to the low hydraulic conductivity of this subsurface geology (Shamsudduha et 432 al. 2011). Hence, earlier evidence indicates that rigorous abstraction of groundwater for 433 irrigation, decreasing precipitation that is one of the impacts of climate change and local geology 434 of the study region, can be attributed to rapidly declining GWL in the drought-prone urban area.

435 The decreasing rate of GWTs may be due to decline recharge resulted from low rainfall, an 436 expanding plough pan triggering from enhancing conservation agriculture practices, and a thick 437 silty clay surface in the Khetlal Upazila. In this Upazila, the rainfall has reduced by $12-80$ $438 \mathrm{~mm} /$ year, decreasing natural recharge over the past ten years (Jahan et al. 2010). The abuse of 439 existing GWL, primarily being extracted for paddy farming, rice mill operations, and other 440 industrial purposes, is an alarming issue that affects the Khetlal Upazila, where groundwater 441 provides $80 \%$ of the water needed for rice irrigation. Here, random use of water in industry and 
442 agriculture is causing GWL declination. Inefficient use of water for domestic and irrigation 443 purposes leads to over-extraction of groundwater and also contributes, to some extent, to 444 declining GWTs. On average, GWL varies between 1 and $6 \mathrm{~m}$ in the northern region, consistent 445 with the Master Plan Organization (MPO 1987) claim, which states that groundwater is mainly 446 available within $5 \mathrm{~m}$ of ground within alluvial aquifers. Evidence suggests that aquifer 447 replenishment slowly ends during the dry season due to low rainfall in the short monsoon season 448 and less available soil moisture (Jahan et al., 2010; Zinat et al. 2020). This is primarily because 449 of more groundwater mining than aquifer recharge (Salam et al. 2020b). The over-exploitation of 450 groundwater for irrigation without any rise in rainfall triggered a decline in GWLs to some 451 degrees. They cannot be replenished naturally, which has caused a groundwater deficit in this 452 drought-prone region of Bangladesh (Hasanuzzaman et al., 2017).

453 Our study has some implications for sustainable groundwater development. Utilizing 454 underutilized rivers, measuring aquifers' safe yields, recharging the aquifers by natural and 455 artificial ways, harvesting rainwater, and using wastewater are the possible choices for this 456 alternative (Jahan et al. 2010; Dey et al. 2017; Islam et al. 2019). Suppose rainfall collects in 457 sustainable ways during the monsoon season used for domestic purposes, after the low-cost 458 filtering process. In that case, this will substantially lessen the water shortage issue in the 459 northwest region in the long run. To aid this, rainwater harvesting facilities should be properly 460 planned and designed based on our findings (Islam et al. 2019), a substantial performance in the 461 Khetlal and Kalaiupazilas that need collaborative efforts among governments non-government 462 organizations, and hydro-geologist. Also, practices such as mulching can increase the water463 holding capacity of field soils and decrease evaporation. Organic mulching can also aid 464 groundwater recharge by increasing soil organic matter, especially drought-prone Upazilas such 
465 as Khetlal, Kalai. Rapid urbanization, climate change, and poor water management policy 466 threaten groundwater resources in the study area, perplexing their sustainable management. 467 Thus, strategies such as artificial recharge of aquifers, rainwater harvesting, water-saving 468 technologies, and integrated water resources management must be implemented.

469 Groundwater study must be coupled with other geoscience and hydro-engineering researches. 470 Multi-disciplinary tools should require managing in case of GWL depletion in a sustainable 471 manner. Groundwater should be used as a supplement to surface water. Deep insight and 472 protection of groundwater for future communities, particularly overexploitation, should be 473 monitored from time to time and a strengthened legal approach (Bhattacharjee et al. 2019). GWR 474 management must persistent forthcoming period; thus, future groundwater problems cannot be 475 neglected (Dey et al., 2017). Thus, sustainable GWR management depends on precisely 476 evaluating groundwater resources' current and future trend patterns (Richter et al., 2006). This 477 study concentrates on assessing the present and forthcoming trends of GWL in the Joypurhat 478 district of northwest Bangladesh, which covers how decision-makers take the right initiative for 479 combined sustainable GWR management. The increased irrigation coverage linkage with 480 increased groundwater extraction from the aquifers over the recent past has attributed to a 481 decrease in GWLs. Hence, the northwest region, especially the Barind area, is of most alarming 482 over dropping GWL, which leads to a lack of access to water for drinking and irrigation in 483 several regions. GWL declination can have an irreversible concern on the drinking water and 484 particularly on the human health issues. Hence, continuous monitoring of GWL fluctuation using 485 an easy but practical tool is essential for GWR management.

486 Some of the vital indicators of GWL fluctuations, including bore-well depths closeness of well 487 from sink or source and hydrogeological features, e.g., aquifer porosity and permeability, are 
488 ignored in this study due to unavailability data. Further investigation is essential by incorporating 489 these critical hydrogeological parameters in data-driven tools to enhance short and mid-term 490 prediction accuracy and confirm these hybrid methods agree well with the theoretical and 491 numerical-based approaches. Such understanding could give further numerical insights and 492 would probably lead to a higher acceptance of soft computing methods in the sustainable 493 management of GWR. Further study should consider all the wells for predicting regional and 494 national levels GWL.

\section{5. Conclusion}

496 Groundwater declination has been a burning issue globally as well as regionally in recent times.

497 This study represents how alarming the GWL depletion is in the study area. This research proves 498 the magnitudes of GWL fluctuation scenarios obtained from the modified Mann- Kendall test, 499 Sen's slope estimator, Pettitt's test. The ARIMA modeling outcomes are realistic and consistent 500 with the present condition. The study shows a decreasing trend of GWL, and the declination rate 501 of GWL in Joypurhat district is $0.136 \mathrm{~m} / \mathrm{yr}$ from 1980 to 2019 . Out of five Upazilas, the 502 groundwater declination rates of Khetlal and Kalai are higher than the district average, which is 503 liable to excessive groundwater abstraction in high water-consuming crop production like rice 504 and potato. The forecasted results revealed that the GWL will go down from 2020-2050 at a rate 505 of $0.143 \mathrm{~m} / \mathrm{yr}$, which is very more alarming in the future sustainability of groundwater resources. 506 In this study area, proper crop water management should be emphasized to avoid such adverse 507 impacts. Though rainwater harvesting is recommended as a long-time remedy to cope with 508 drought effects, simultaneous monitoring can be a short-term remedy. Future research should 509 concentrate on GWL fluctuation tele-connected with large-scale atmospheric oscillation in the 
510 study region. Our study provides sustainable groundwater potentiality under current and future

511 climate change scenarios in the northwest region of Bangladesh.

512 Acknowledgement

513 The authors would like to express their gratefulness to the Bangladesh Meteorological Department (BMD) and

514 the Bangladesh water development board (BWDS) for sharing data for this research.

515 Ethical approval

$516 \quad$ Not applicable

517 Consent to Participate

$518 \quad$ Not applicable

519 Consent to Publish

$520 \quad$ Not applicable

521 Data availability

522 Data are available upon request on the corresponding author

523 Code availability

524 Not applicable

525 Author contributions

526 A.R, A.I and A.R.M.T, designed, planned, conceptualized, drafted the original manuscript, and R.S., and 527 A.R., M.A., were involved in statistical analysis, interpretation; M.T.A., R.S., and A.R., contributed 528 instrumental setup, data analysis, validation; A.R.M.T., M.A. A.I., and A.R., contributed to editing the 529 manuscript, literature review, proofreading; A.R. and A.R.M. T.I., were involved in software, mapping, 530 and proofreading during the manuscript drafting stage.

531 Conflict of interest

532 There is no conflict of interest to publish this work.

$533 \quad$ Funding statement

534 None

References

1. Ajibade F, Olajire, O. ., Ajibade, T., et al. 2021. Groundwater potential assessment as a preliminary step to solving water scarcity challenges in Ekpoma, Edo State, Nigeria. Acta Geophys. 69, 1367-1381. https://doi.org/10.1007/s11600-021-00611-8 
2. Akhter, S., Eibek, k U, Islam, S., Islam, A. R. M. T., Chu, R., \& Shen, S. (2019). Predicting spatiotemporal changes of channel morphology in the reach of Teesta River, Bangladesh using GIS and ARIMA modeling. Quaternary International. https ://doi.org/10.1016/j.quain t.2019.01.022.

3. BADC (Bangladesh Agriculture Development Corporation) 2019. Minor irrigation survey report 2019, Dhaka, Bangladesh

4. Bayley GV, Hammersley JM (1946) The" effective" number of independent observations in an autocorrelated time series. Supplement to the J R Stat Soc. 8(2):184-97

5. Bhattacharjee S, Saha B, Saha B, Uddin MS, Panna CH, Bhattacharya P, Saha R (2019) Groundwater governance in Bangladesh: Established practices and recent trends. Groundwater for Sustainable Development8:69-81

6. Box GE, Jenkins GM. (1976) Time series analysis, forecasting and control. Holden Day: San Francisco, California, USA, pp. 625

7. Das S, Islam ARMT (2021) Assessment of mapping of annual average rainfall in a tropical country like Bangladesh: remotely sensed output vs. kriging estimate, Theoretical and Applied climatology, DOI: 10.1007/s00704-021-03729-3

8. Das, S., 2021. Extreme rainfall estimation at ungauged locations: Information that needs to be included in low-lying monsoon climate regions like Bangladesh. J. Hydrol. 601, 126616.

9. Dey NC, Saha R, Parvez M, Bala SK, Islam AS, Paul JK, Hossain M (2017) Sustainability of groundwater use for irrigation of dry-season crops in northwest Bangladesh. Groundw. Sustain. Dev. 4:66-77.https://doi.org/10.1016/j.gsd.2017.02.001

10. Ghose B, Islam ARMT, Kamruzzaman M, Moniruzzaman M, Hu Z (2021) Climate-induced rice yield anomalies linked to large-scale atmospheric circulation in Bangladesh using multistatistical modeling, Theoretical and Applied climatology, DOI: 10.1007/s00704-02103584-2

11. Hamed KH, Rao AR. A (1998) modified Mann-Kendall trend test for autocorrelated data. J. Hydrol.204(1-4):182-96.https://doi.org/10.1016/S0022-1694(97)00125-X

12. Hasanuzzaman, M., Song, X., Han, D., Zhang, Y., Hussain, S. (2017) Prediction of Groundwater Dynamics for Sustainable Water Resource Management in Bogra District, Northwest Bangladesh, Water 2017, 9, 238; doi:10.3390/w9040238. 
13. Hossain MI, Islam MT, Matin I (2015) Groundwater Resources Assessment For Joypurhat District Using Mathematical Modelling Technique. Am. J. Eng. Res. 4(6):137-143

14. Husna, N.E., Bari, S.H., Hussain, M.M., Ur-Rahman, M.T., Rahman, M. (2016). Ground water level prediction using artificial neural network. International Journal of Hydrology Science and Technology, 6 (4), 371-381.

15. Institute of Water Modelling (IWM), "Groundwater Resource Study and Decision Support System Development of Thakurgaon, Panchagarh, Dinajpur, Joypurhat Districts and also Remaining Districts of Rajshahi Division Through Mathematical Model Study", 2009, Final Report, Volume-II.

16. IRRI (International Rice Research Institute) (2010) World Rice Statistics (WRS), Manila, Philippines

17. Islam ARMT, Rahman MS, Khatun $\mathrm{R}, \mathrm{Hu} Z$ (2020) Spatiotemporal trends in the frequency of daily rainfall in Bangladesh during 1975-2017, Theoretical and Applied climatology, Springer, SCOPUS/ISI Index, IF: 3.17, 141(3-4), 869-887. DOI: 10.1007/s00704-020-03244-x

18. Islam ARMT, Shen S, Yang SB, Hu Z, Chu R (2019) Assessing recent impacts of climate change on design water requirement of Boro rice season in Bangladesh, Theoretical and Applied Climatology, 138(1-2):97-113, https://doi.org/10.1007/s00704-019-02818-8

19. Islam ARMT, Talukdar S, Mahato $S$ et al. (2021b). Flood susceptibility modelling using advanced ensemble machine learning models. Geoscience Frontiers, 12, 101075, doi: 10.1016/j.gsf.2020.09.006

20. Islam ARMT, Shen S, Haque MA, et al. (2018) Assessing groundwater quality and its sustainability in Joypurhat district of Bangladesh using GIS and multivariate statistical approaches, Environment, Development and Sustainability, 20(5): 1935-1959. doi: 10.1007/s10668-017-9971-3

21. Islam ARMT, Talukdar S, Mahato S, Ziaul SK, Eibek KU, Akhter S, Pham QB, Mohammadi B, Karimi F, Linh NTT (2021a) Machine learning algorithm-based risk assessment of riparian wetlands in Padma River Basin of Northwest Bangladesh, Environment Science and Pollution Res, DOI: 10.1007/s11356-021-12806-z. 
22. Islam, A. R. M. T., Shen, S., Yang, S., Hu, Z., \& Chu, R. (2019). Assessing recent impacts of climate change on design water requirement of Boro rice season in Bangladesh. Theoretical and Applied Climatology. https ://doi.org/10.1007/s0070 4-019-02818 -8.

23. Jahan CS, Mazumder QH, Islam AT, Adham MI (2010) Impact of irrigation in Barind area, NW Bangladesh - an evaluation based on the meteorological parameters and fluctuation trend in groundwater table. J. Geol. Soc. India. 76(2):13442.https://doi.org/10.1007/s12594-010-0085-x

24. Jerin JN, Islam ARMT, Mamun MAA, Mozahid MN, Ibrahim SM (2021) Climate change effects on potential evapotranspiration in Bangladesh, Arabian Journal of Geosciences, 14, 682, DOI: 10.1007/s12517-021-07010-9

25. Kalhor, K., Emaminejad, N. (2019). Sustainable development in cities: Studying the relationship between groundwater level and urbanization using remote sensing data. Groundwater for Sustainable Development, pp. 100243

26. Kendall, M.G., 1975. Rank Correlation measures. 1. Charles Griffin, London, pp. 25-55.

27. Mackay JD, Jackson CR, Brookshaw A, Scaife AA, Cook J, Ward RS (2015) Seasonal forecasting of groundwater levels in principal aquifers of the United Kingdom. J. Hydrol. 530, 815-828.https://doi.org/10.1016/j.jhydrol.2015.10.018

28. Mann, H.B., 1945. Nonparametric tests against trend. Econometrica 13, 245-259, 00129682(194507)13:3.

29. Mallick J, Talukder S, Islam ARMT, et al. (2021) Proposing receiver operating characteristic-based sensitivity analysis with introducing swarm optimized ensemble learning algorithms for groundwater potentiality modelling in Asir region, Saudi Arabia, Geocarto International, Taylor and Francis, SCOPUS/ISI Index, IF: 4.88, DOI: $10.1080 / 10106049.2021 .1878291$

30. Morris BL, Lawrence AR, Chilton PJ, Adams B, Calow RC, Klinck BA (2003) Groundwater and its susceptibility to degradation: a global assessment of the problem and options for management.

31. MPO (Master Plan Organization) (1987) Groundwater resources of Bangladesh, Technical Report no 5. (Dhaka: Master Plan Organization) Hazra, USA; Sir M MacDonald, UK; Meta, USA; EPC, Bangladesh. 
32. Park YC, Jo YJ, Lee JY (2011) Trends of groundwater data from the Korean National Groundwater Monitoring Stations: indication of any change? Geosci. J. 15(1):105-14. https://doi.org/10.1007/s12303-011-0006-Z

33. Patle GT, Singh DK, Sarangi A, Rai A, Khanna M, Sahoo RN (2015) Time series analysis of groundwater levels and projection of future trend.J. Geol. Soc. India. 85(2):232-42.https://doi.org/0016-7622/2015-85-2-232/\$

34. Pettit AN (1979). A non-parametric approach to the change-point problem. J. Appl. Stat.28(2):126-135.https://doi.org/10.2307/2346729

35. Praveen B, Talukdar S, Shahfahad, Mahato S, Mondal J, Sharma P, Islam ARMT, Rahman A (2020) Analyzing trend and forecasting of rainfall changes in India using nonparametrical and machine learning approaches, Scientific Report, 10(1): 10342, https://doi.org/10.1038/s41598-020-67228-7

36. Rahman AS, Kamruzzama M, Jahan CS, Mazumder QH (2016) Long-term trend analysis of water table using 'MAKESENS'model and sustainability of groundwater resources in drought prone Barind area, NW Bangladesh. J. Geol. Soc. India. 87(2):17993.https://doi.org/10.1007/s12594-016-0386-9

37. Rahman MA, Yunsheng L, Sultana N (2017) Analysis and prediction of rainfall trends over Bangladesh using Mann-Kendall, Spearman's rho tests and ARIMA model. Meteorology and Atmospheric Physics. 129(4):409-24. https://doi.org/10.1007/s00703016-0479-4

38. Rahman MS, Azad MAK, Hasanuzzaman M, Salam R, Islam ARMT, Rahman MM, Hoque MMM (2021). How air quality and COVID-19 transmission change under different lockdown scenarios? A case from Dhaka city, Bangladesh, Science of the Total Environment, Elsevier, 762, 143161, doi: 10.1016/j.scitotenv.2020.143161

39. Reimann KU, Hiller K (1993). Geology of Bangladesh.Stuttgart, Germany

40. Richter, B. D., Warner, A. T., Meyer, J. L., \& Lutz, K. (2006). A collaborative and adaptive process for developing environmental flow recommendations. River Research Application, 22(3), 297-318.

41. Rushton KR, Zaman MA, Hasan M (2020) Monitoring groundwater heads and estimating recharge in multi-aquifer systems illustrated by an irrigated area in north-west 
Bangladesh. Sustain. Water Resour. Manag. 6(2):1-2.https://doi.org/10.1007/s40899-02000382-y

42. Salam R, Islam ARMT, Pham QB, Dehghani M, Al Ansari N, Linh NTT (2020b) The optimal alternative for quantifying reference evapotranspiration in climatic sub-regions of Bangladesh, Scientific Reports, Sci Rep 10 (1), 20171, DOI: 10.1038/s41598-020-77183-y

43. Salam R, Islam T, Md AR, Islam S (2020) Spatiotemporal distribution and prediction of groundwater level linked to ENSO teleconnection indices in the northwestern region of Bangladesh. Environ. Dev. Sustain. 5:4509-35.https://doi.org/10.1007/s10668-019$\underline{00395-4}$

44. Sen, P. (1968). Estimates of the regression coefficient based on Kendall's tau. Journal of the American Statistical Association, 63, 1379-1389

45. Shahid S (2011) Impact of climate change on irrigation water demand of dry season Boro rice in northwest Bangladesh. Clim. Change. 105(3):433-53. DOI 10.1007/s10584-0109895-5

46. Shahid S, Hazarika MK (2010) Groundwater drought in the northwestern districts of Bangladesh. Water Resour. Manag.24(10):1989-2006.https://doi.org/10.1007/s11269009-9534-y

47. Shahid S, Hazarika MK. 2010. Groundwater drought in the northwestern districts of Bangladesh. Water Resources Management, 24(10): 1989-2006. https://doi.org/10.1007/s11269-009-9534-y.

48. Shahid, S. (2011). Impact of climate change on irrigation water demand of dry season Boro rice in North-west Bangladesh. Climate Change, 105, 433-453

49. Shamsudduha M, Taylor RG, Ahmed KM, Zahid A (2011) The impact of intensive groundwater abstraction on recharge to a shallow regional aquifer system: evidence from Bangladesh. Hydrogeol. J. 19(4):901-16. https://doi.org/10.1007/s10040-011-0723-4

50. Sumiya NN, Khatun H (2016) Groundwater variability in bangladesh: assessment based on rainfall variation and use of water in irrigation. J. Asiat. Soc. Bangladesh, Sci.42(2):177-89. https://doi.org/10.3329/jasbs.v42i2.46221

51. WARPO (Water Resources Planning Organization) (2000) National Water Management Plan Project, Draft Development Strategy. Main final, vol 2, WARPO, Dhaka 
52. Yadav, B., Gupta, P.K., Patidar, N., Himanshu, S.K., (2020) Ensemble modelling framework for groundwater level prediction in urban areas of India, Sci Total Environ, 712, 135539.

53. Yue S, Wang C (2004). The Mann-Kendall test modified by effective sample size to detect trend in serially correlated hydrological series. Water Resour. Manag. 18(3):20118

54. Zafor MA, Alam MJ, Rahman MA, Amin MN (2017) The analysis of groundwater table variations in Sylhet region, Bangladesh. Environ. Eng. Res.22(4):369-76.doi. org/10.4491/eer.2016.152

55. Zahid A (2015) Groundwater management aspects in Bangladesh. Technical Report 2015 May

56. Zannat F, Islam ARMT, Rahman MA (2019) Spatiotemporal variability of rainfall linked to ground water level under changing climate in northwestern region, Bangladesh, European Journal of Geosciences - 1(1), 35-56

57. Zinat MR, Salam R, Badhan MA, Islam AR (2020) Appraising drought hazard during Boro rice growing period in western Bangladesh. Int. J. Biometeorol. 64(10):168797.https://doi.org/10.1007/s00484-020-01949-2 
Figures

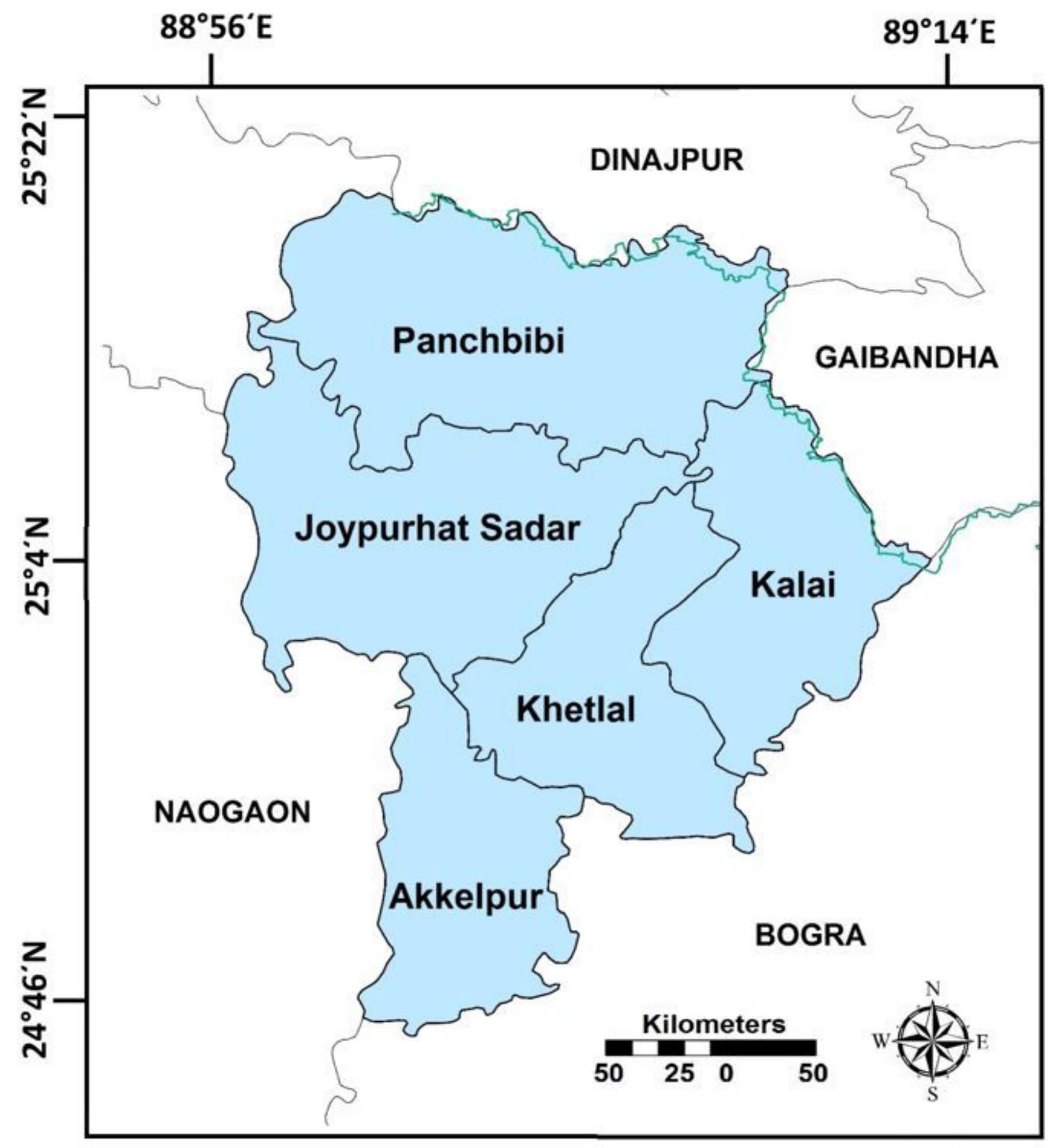

Figure 1

Location of study area (Joipurhat, Bangladesh) map 

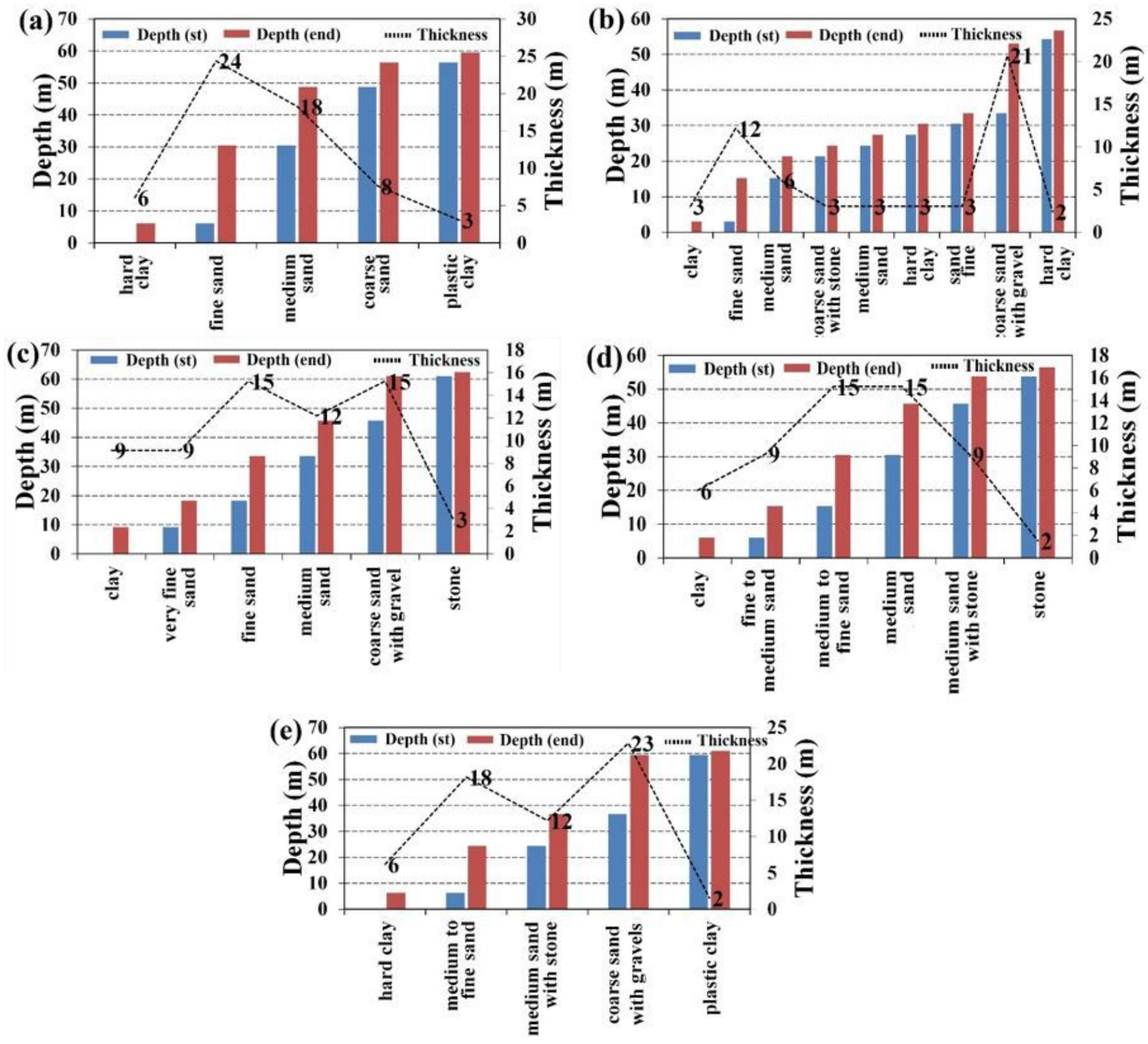

Figure 2

Lithological characteristics of (a) Akkelpur; (b) Panchbibi; (c) Khetlal; (d) Kalai; and (e) Joypurhat sadar 

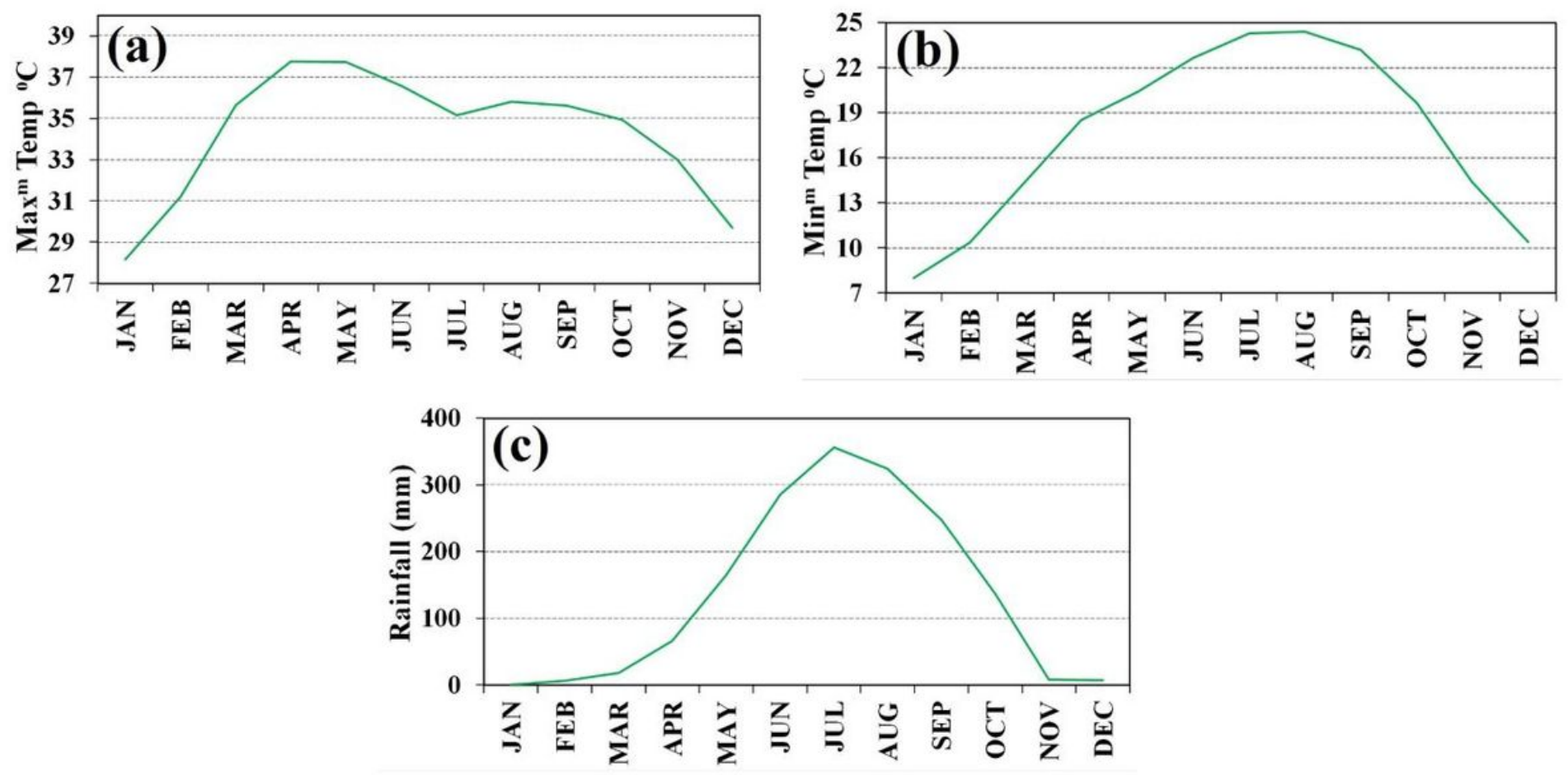

Figure 3

Monthly average (a) Maximum; and (b) Minimum temperature, and (c) rainfall (1980-2019) 

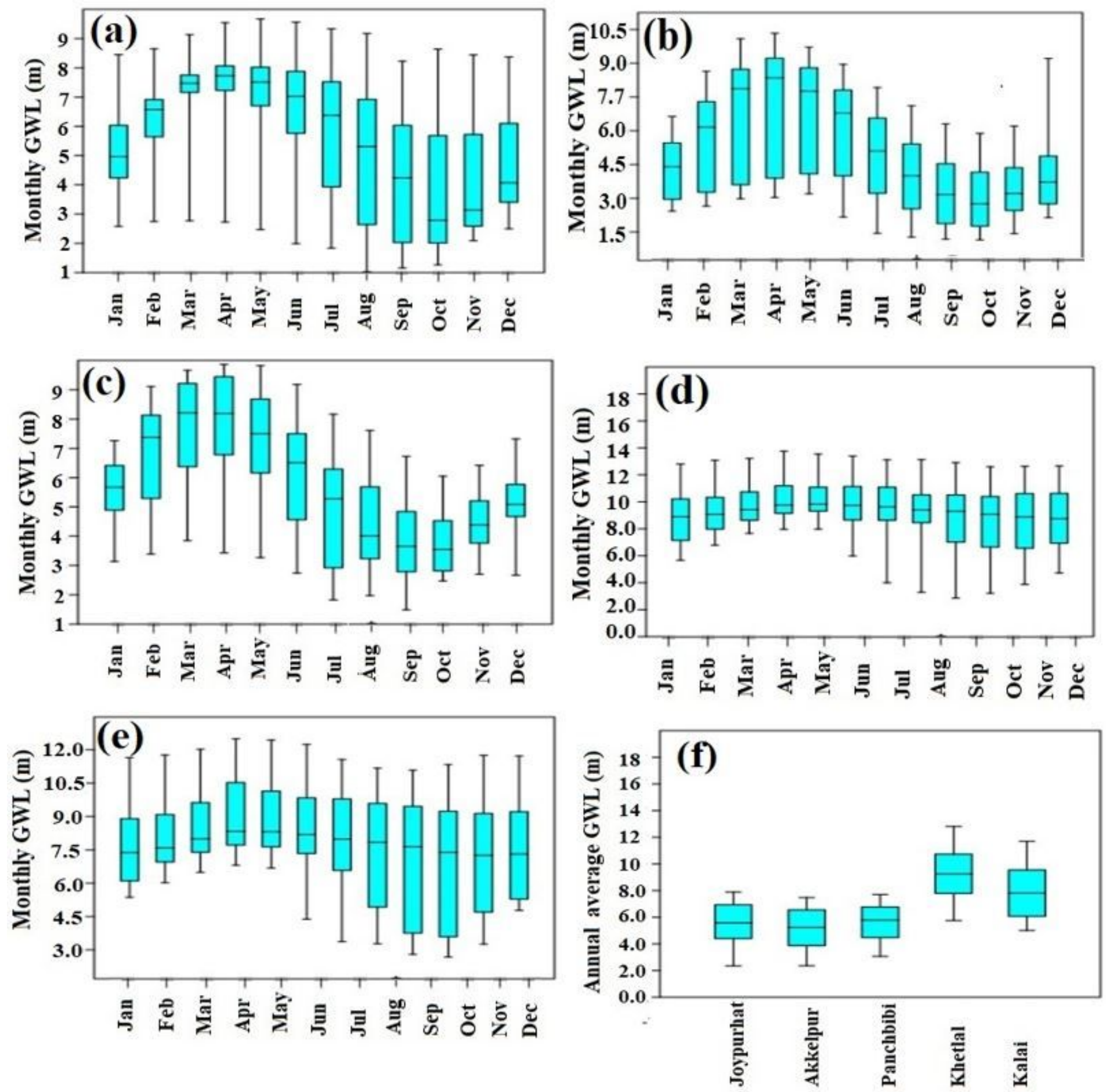

Figure 4

Monthly ground water level variation in (a)Joypurhat Sadar; (b) Akkelpur;(c) Panchbibi; (d) Khetlal;(e) Kalai; and (f) Apparent variation of GWL Joypurhat district 

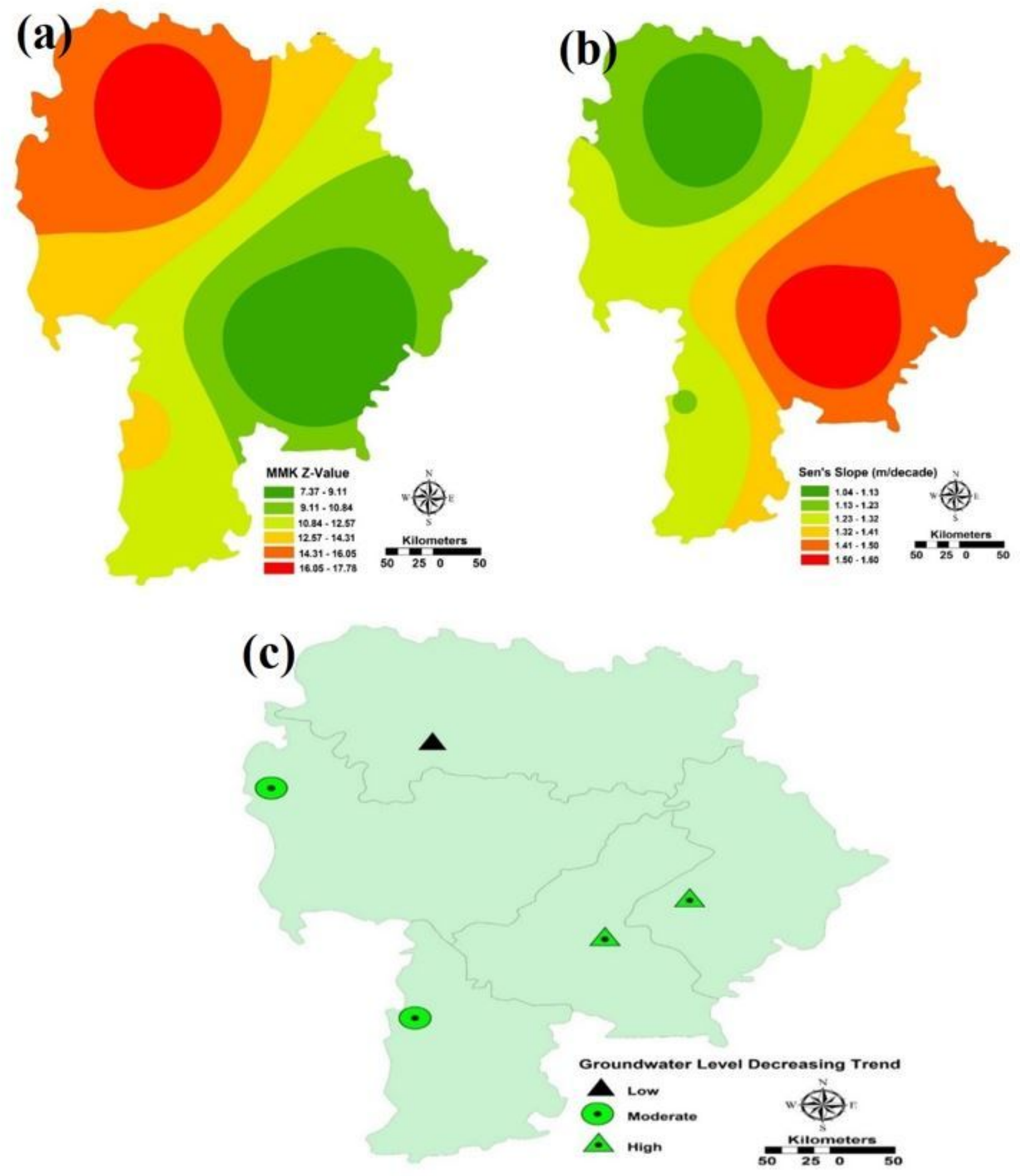

Figure 5

(a) GWL declining trend analysis based on MMK test; (b) GWL trend slope analysis; and (c) Monthly GWL trend analysis (1980-2019) 


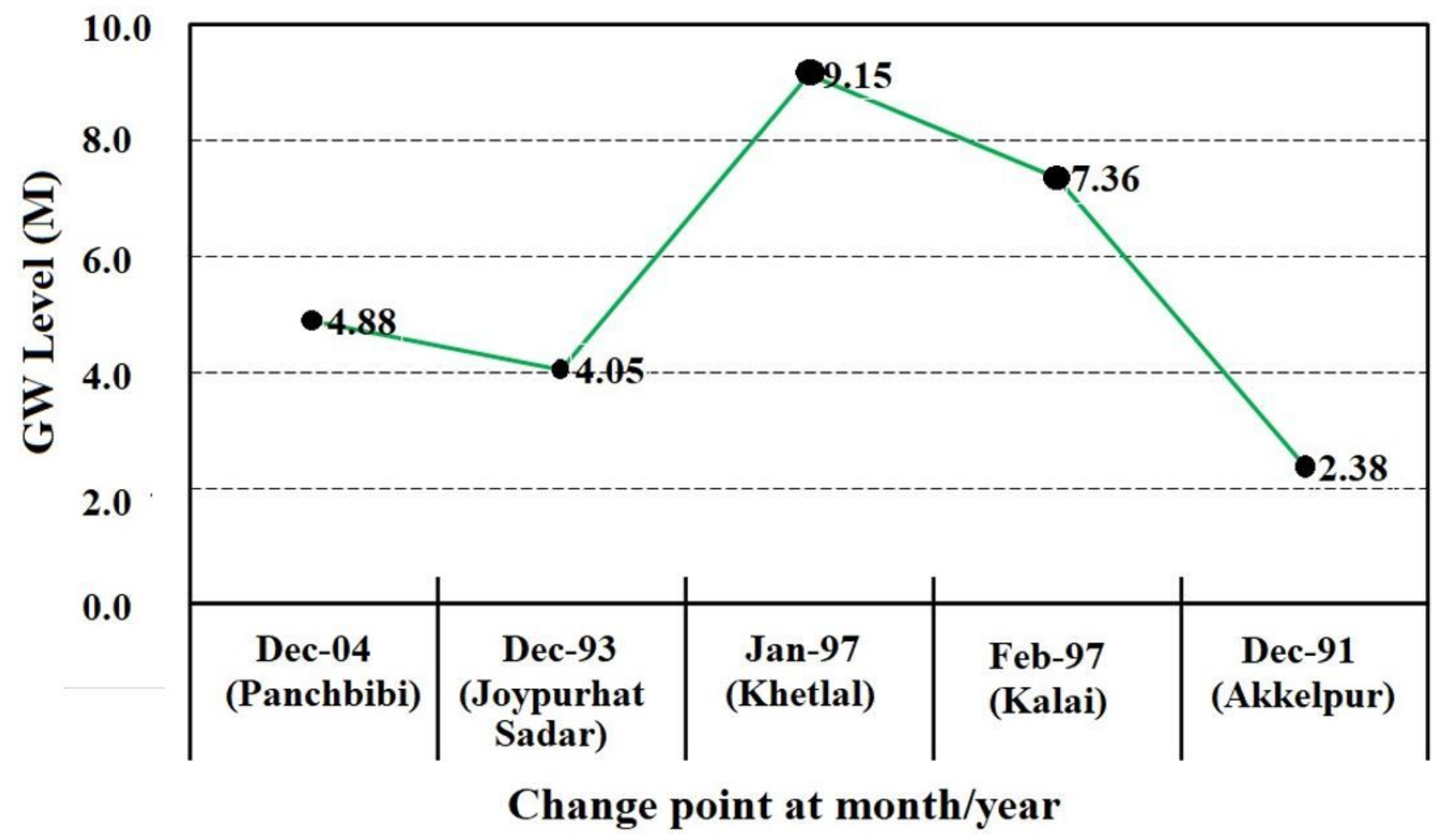

Figure 6

Change point detection time of GWL declination in Joypurhat district. 

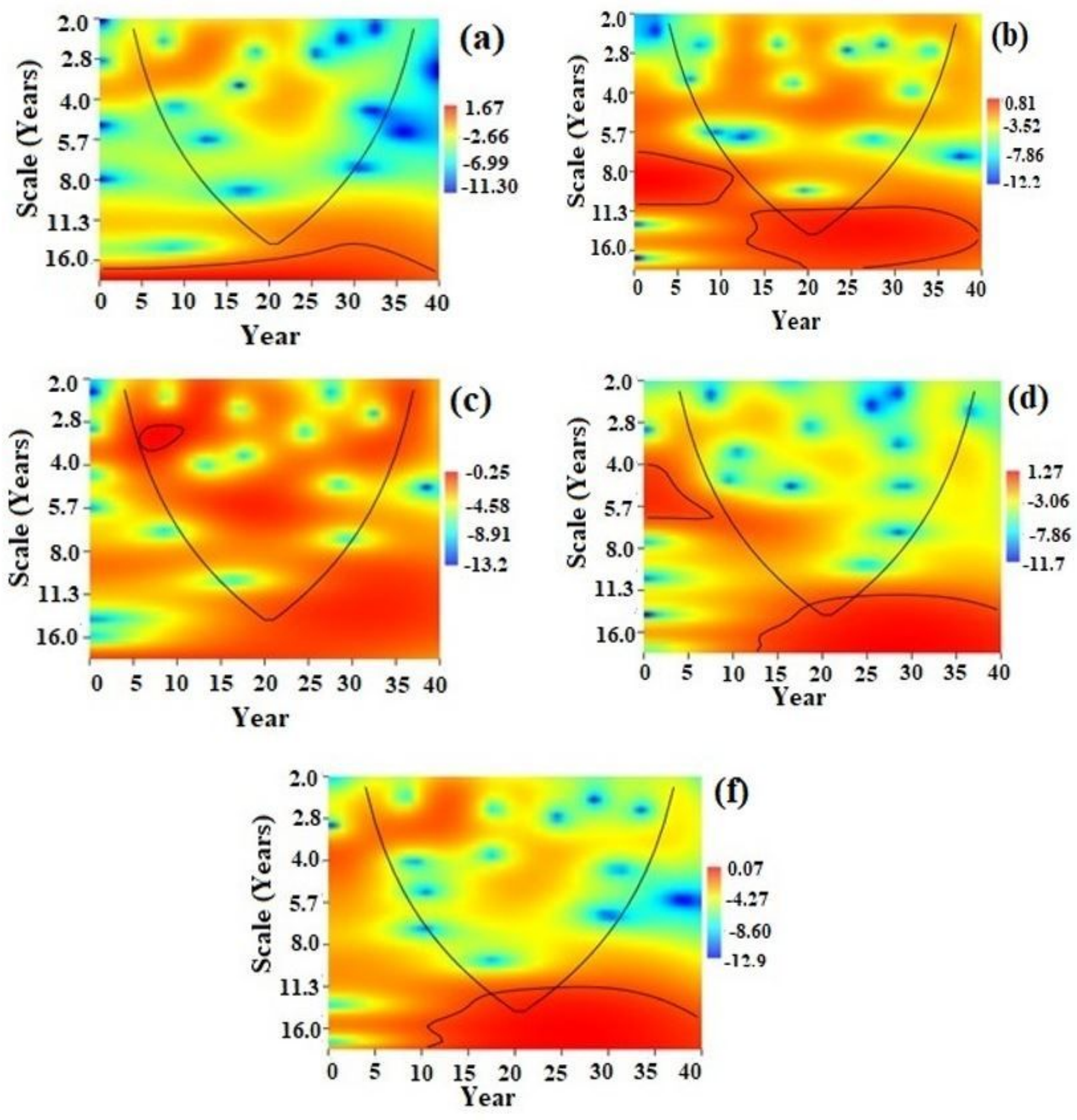

Figure 7

Wavelet power spectrum of ground water level (a) Joypurhat sadar; (b) Akkelpur; (c) Panchbibi; (d) Khetlal; (e) Kalai; and (f) Joypurhat District 

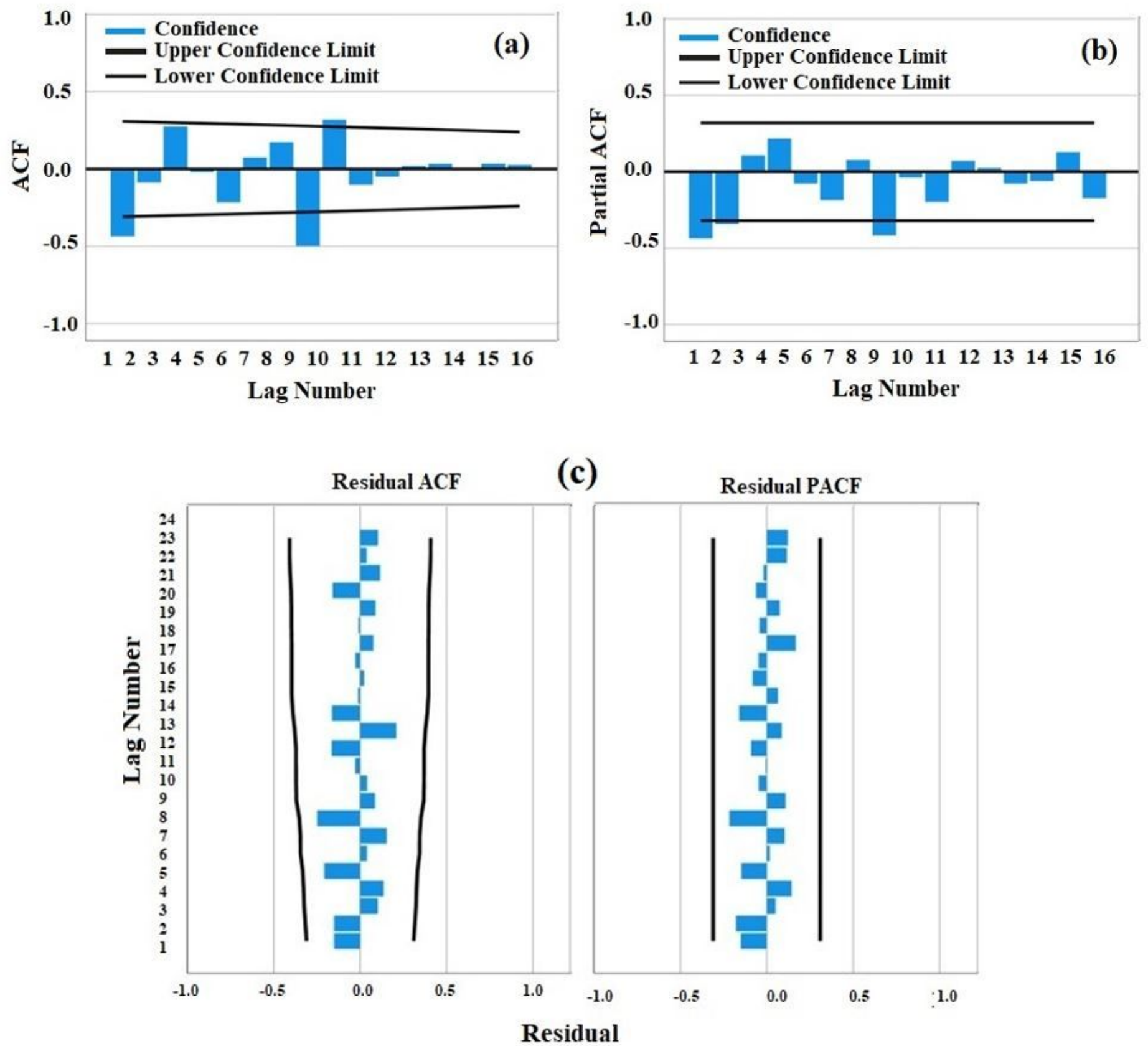

Figure 8

Autocorrelation plot (a) ACF without differentiating; (b) PACF without differentiating; and (c) ACF and PACF with differencing of ground water levels in Joypurhat district 


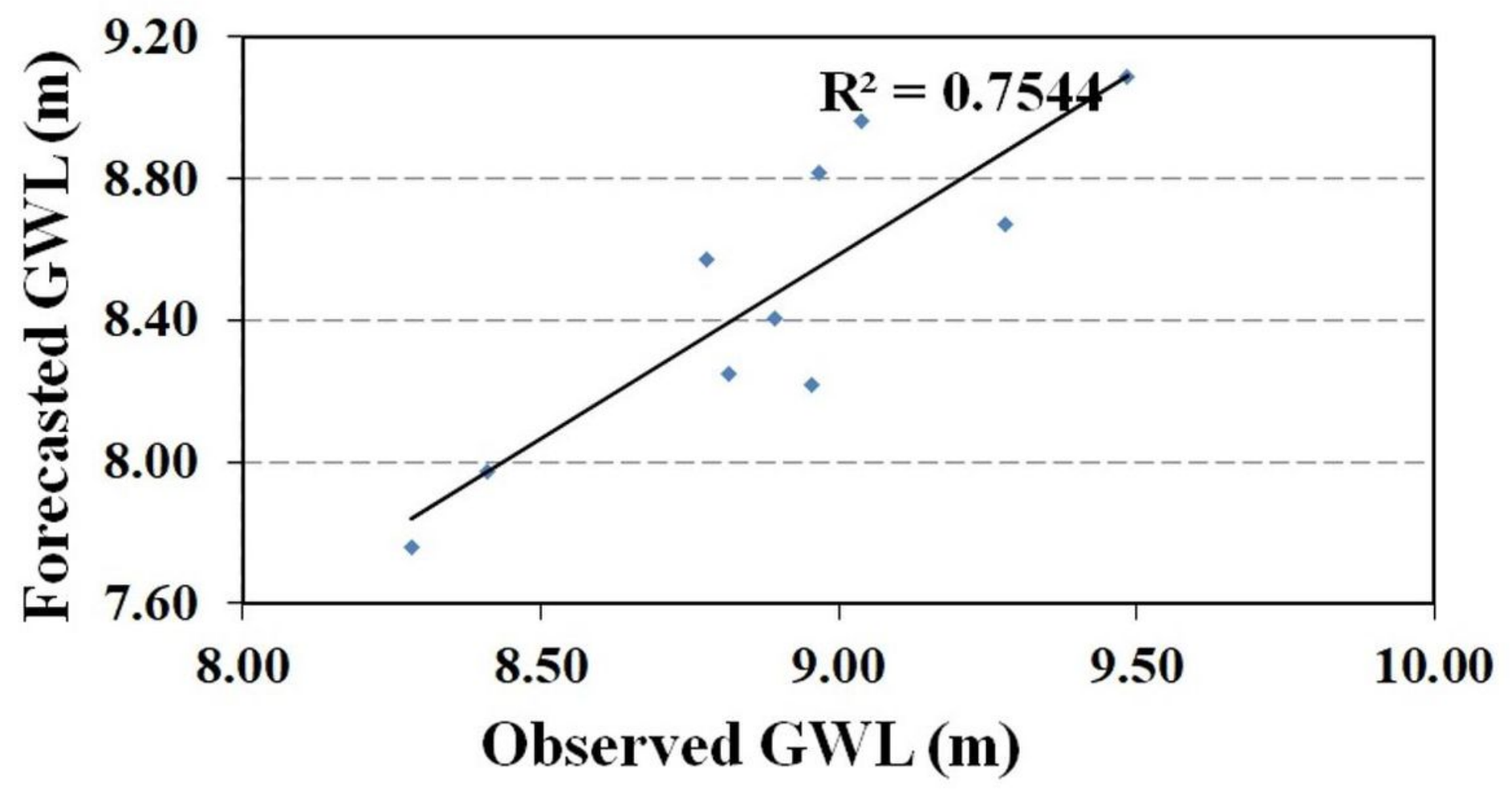

Figure 9

Comparison plot of observed versus forecasted ground water levels (2010-2019) of Joypurhat district. 

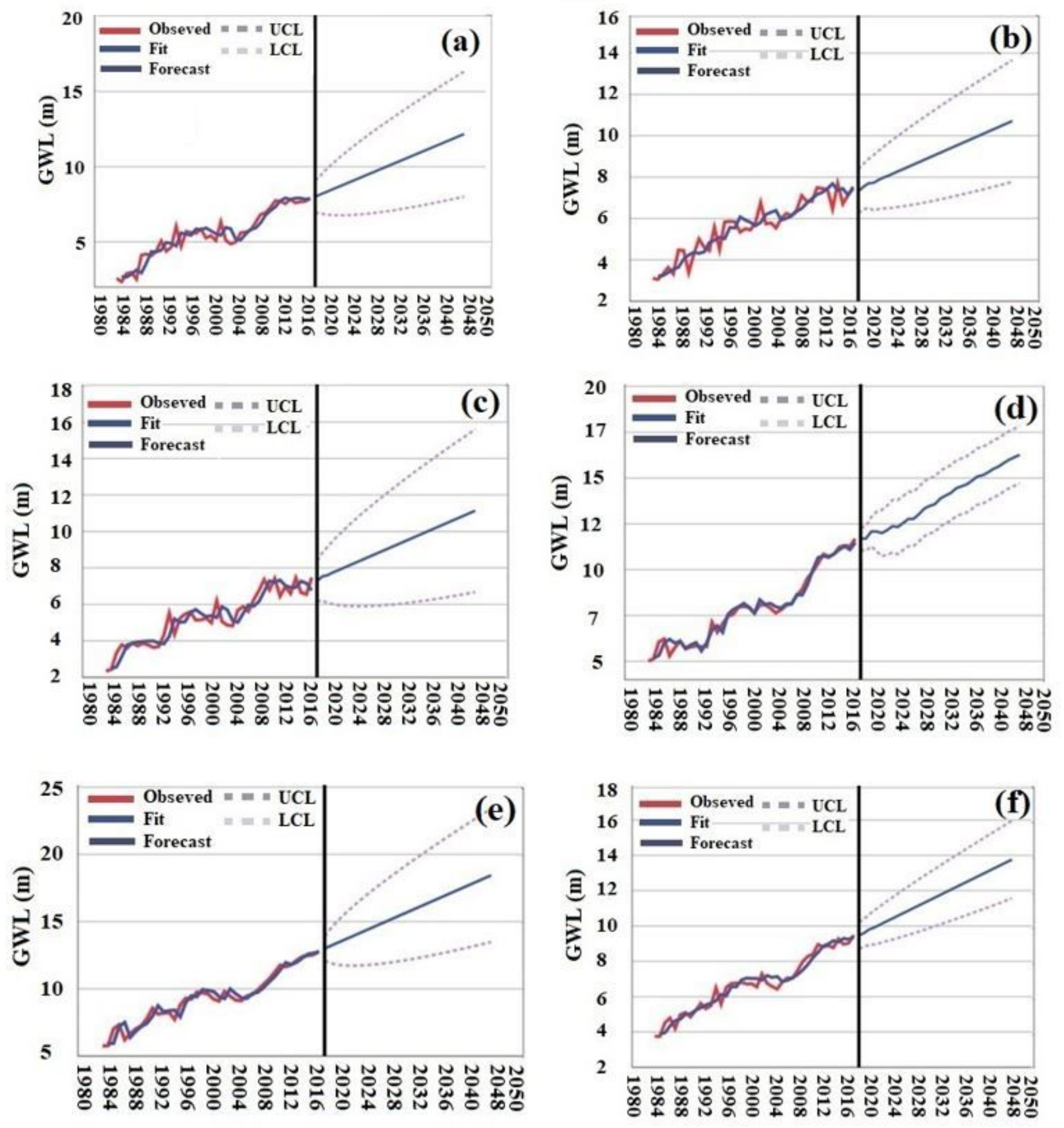

\section{Figure 10}

Forecasting of groundwater level by best ARIMA model fitting(a)Model 1,1,0 (Joypurhat sadar); (b) Model 2,1,0 (Panchbibi); (c)Model 1,1,0 (Akkelpur); (d) Model 8,1,8 (Kalai); (e) Model 0,1,0 (Khetlal); and (f) Model 2,1,0 (Joypurhat district) 